\title{
A MACROANATOMIC, MORPHOMETRIC AND COMPARATIVE INVESTIGATION ON SKELETAL SYSTEM OF THE GEESE GROWING IN KARS REGION II: SKELETON APPENDICULARE
}

\author{
Gülseren KIRBAŞ DOĞAN ${ }^{1 *}$, İsmet TAKCI ${ }^{1}$ \\ ${ }^{1}$ Department of Anatomy, Faculty of Veterinary Medicine, Kafkas University, 36100, Kars, Turkey
}

\begin{abstract}
The aim of this study was to comparatively, morphometrically and macroanatomically investigate skeleton appendiculare. A total of 24 goose cadavers were used. Scapula length was $107.31 \pm 1.05 \mathrm{~mm}$ in female geese; it was $116.63 \pm 0.65 \mathrm{~mm}$ in male ge ese. While the length of the os coracoideum was $78.5 \pm 0.6 \mathrm{~mm}$ in female geese; it was detected as $87 \pm 0.8 \mathrm{~mm}$ in male geese. The clavicula length was $66.90 \pm 0.71 \mathrm{~mm}$ in female geese and it was $73.39 \pm 0.59 \mathrm{~mm}$ in male geese and it was determined that both clavicula shaped furcula with a distinct curvature. While the length of the humerus in female geese was $175.02 \pm 1.59 \mathrm{~mm}$; it was measured as $191.28 \pm 1.44 \mathrm{~mm}$ in male ones. While the mean ulna height was $162.60 \pm 1.26 \mathrm{~mm}$ in female geese; it was determined as $178.84 \pm 0.83$ $\mathrm{mm}$ in male geese. The mean radius length was measured as $154.20 \pm 1.63 \mathrm{~mm}$ in female geese, it was $169.75 \pm 1.31 \mathrm{~mm}$ in male geese. It was detected that os carpi radiale was in a triangular shape, os carpi ulnare was in the form of a pipe. It was determined that the height of carpometacarpus was $94.57 \pm 0.75 \mathrm{~mm}$ in female geese; $100.95 \pm 1.03 \mathrm{~mm}$ was in male geese. Pelvis length was measured as $154.27 \pm 1.81 \mathrm{~mm}$ in female geese; it was $169.91 \pm 1.68 \mathrm{~mm}$ in male geese. While femur length was detected as $86.85 \pm 0.98 \mathrm{~mm}$ in female geese; it was $93.87 \pm 1.12 \mathrm{~mm}$ in male geese. While tibiotarsus length was $160.94 \pm 1.88 \mathrm{~mm}$ in female geese; it was $174.20 \pm$ $1.28 \mathrm{~mm}$ in male ones. While the tarsometatarsus length was $93.15 \pm 1.19 \mathrm{~mm}$ in female geese; it was measured as $101.64 \pm 0.88 \mathrm{~mm}$ in male geese. As a result, in this study, thought that obtained findings will contribute in scientific research, evaluations of sexual dimorphism, zooarchaeological studies and operations on poultry animals.
\end{abstract}

Keywords: Anatomy, Goose, Kars, Poultry, Skeleton appendiculare

*Corresponding author: Department of Anatomy, Faculty of Veterinary Medicine, Kafkas University, 36100, Kars, Turkey

E mail: glsrn36@gmail.com (G. KIRBAȘ DOĞAN)

Gülseren KIRBAŞ DOĞAN (iD) https://orcid.org/0000-0003-3770-9956 Received: September 26, 2020

İsmet TAKCI (iD) https://orcid.org/0000-0003-4795-3864

Accepted: October 05, 2020

Published: January 01, 2021

Cite as: Kirbaş Doğan G, Takcı İ. 2021. A macroanatomic, morphometric and comparative investigation on skeletal system of the geese growing in Kars region II: Skeleton appendiculare. BSJ Health Sci, 4(1): 6-16.

\section{Introduction}

One of the main issues of people today is the need for basic food sources. Food from animals is of high importance within this need. The largest source for increasing species diversity in food production is poultry animals. Among waterbirds, geese are at a different position with their species that are raised for multiple purposes and the diversity they provide in production. Among the commercially and economically important yield features of geese are their meat, liver, fat, feathers and eggs (Aslan, 2013). In addition, according to a study (Kılıç et al., 2018), intramedullary mature goose radius as the intramedullary pin was used in the treatment of femoral fractures in puppies and rabbits as organic osteosynthesis material. With this application, which was found to be clinically, radiologically and histopathologically successful, a new usage area for goose bone emerged. Goose is the common name for the large species that constitutes the Anser strain of the Anatidae family from the Anseriformes tribe (Demirsoy, 1995; Tilki and Saatçi, 2013). In poultry, the locomotor system both contains the formations necessary for body balance and movement and reflects individual features. The skeleton constitutes the passive part of the locomotor system along with the joints and the skeletal muscles constitute the active part (Nickel et al., 1977). The most important feature of poultry is that they have pneumatic bones. These bones are in participation with the respiratory system through air sacs (sacci pneumatici). Non-flying poultry do not have pneumatized bones. There are three types of poultry bones: morphologically compact bones, cancellous bones, and medullary bones. In poultry, appendicular skeleton comprises of skeleton of the pectoral girdle, skeleton of the wing, skeleton of the pelvic girdle and skeleton of the pelvic limb. Poultry wing is equivalent to the front legs in mammals. Scapula, os coracoideum and clavicula (two clavicula merge form furcula) creates skeleton of the wing (cingulum membri thoracici) (Dursun, 2007). The wing is followed by these bones respectively; humerus, radius-ulna, carpus, metacarpus and ossa digiti (Nickel et al., 1977). Cingulum thoracic membrane of binding to the osseous in poultry while the body is in mammals muscle (Dyce et al., 1987, McLelland, 1990). Scapula and coracoid bones become smaller in good flightless birds, 
even ostrich was lost (Kuru, 1987). The bones (sacrum, coxa) that make up the ossa cinguli membri pelvici in the mammals are fused as well as the vertebrae lumbicalis (Nickel et al., 1977, König et al., 2016). Ossa membri pelvici consist of; femur, patella, tibiotarsus, fibula, ossa pedis, ossa tarsi, ossa digitorum pedis and phalanges (N.A.A., 1993, Dursun, 2007).

\section{Material and Methods}

The cadavers supplied by breeders who butcher for food were brought to the laboratory of Kafkas University Faculty of Veterinary Science Anatomy Department and the study was conducted there.

A total of 24 goose cadavers; 12 of them female ( 1 old) and 12 male with average weights of $3.25 \pm 0.15 \mathrm{~kg}$ (female) $-3.92 \pm 0.21 \mathrm{~kg}$ (male) were used in the study. The weights of the goose cadavers were recorded with the help of digital precision balances $1 \mathrm{~g}$ of unapproved sensitivity from $0-15 \mathrm{~kg}$, and $2 \mathrm{~g}$ from $15-30 \mathrm{~kg}$, Baykon brand coded BCS21-6 MR). After the superficial muscles of 20 of the geese (10 female, 10 male) were dissected, the bones were revealed by maceration. After the superficial muscles of the geese whose bones are to be studied were dissected, boiling was performed for two hours in the water in which $10-15 \%$ sodium bicarbonate $\left(\mathrm{NaHCO}_{3}\right)$ was added (Taşbaş and Tecirlioğlu, 1965). The bones were thoroughly cleaned after the cooling procedure and soaked in a $10 \%$ hydrogen peroxide $\left(\mathrm{H}_{2} \mathrm{O}_{2}\right)$ solution for two hours to whiten. After the last of the bones were thoroughly washed, they were left to dry in the sun (Taşbaş and Tecirlioğlu, 1965; Mussa et al., 2015). Measurements were taken from all goose bones with the help of a digital caliper and measuring tape in accordance with the method laid out by Von Den Driesch, 1976. Denomination was made in accordance with Nomina Anatomica Avium (N.A.A., 1993).

In order for pneumatic bones to be determined, 1 female and 1 male goose were injected acrylic (takilon), and 1 female and 1 male goose were injected a liquid rubber material (latex) colored with red fabric dye from the trachea for corrosion cast study. Each of the geese was injected with $120 \mathrm{ml}$ of latex. They were then soaked in a $10 \%$ formaldehyde solution and dissected. The muscles were dissected and the pneumatized bones that the latex reached through air sacs were detected. Each of the geese was given $120 \mathrm{ml}$ of an acrylic mixture containing $20 \%$ monomethyl-methacrylate and $80 \%$ plimetylmethacrylate through the trachea. In order to ensure that this mixture solidified, cadavers were soaked in tap water for 24-48 hours. Then, examinations were made after the cadavers were soaked in a $30 \%$ potassium hydroxide $(\mathrm{KOH})$ solution at a temperature of $60^{\circ} \mathrm{C}$ until the tissues were melted in order to make corrosion and cleaned. Thus, pneumatized bones were detected by means of both latex and acrylic. The mean and standard deviation values of all measurements and differences between genders were determined with the independent samples $t$ test in the SPSS (version 20.0) packaged software.

\subsection{Ethical Consideration}

For this study, permission was obtained from Kars Provincial Directorate of Agriculture (dated 31.03.2017 and numbered E.791642) and KAÜ-HADYEK (KAÜHADYEK/2017-047).

\section{Results}

\subsection{Skeleton Appendiculare}

Geese skeleton appendiculare were examined in 4 parts; ossa cinguli membri thoracici, ossa alae, ossa cinguli membri pelvini and ossa membri pelvini.

3.1.1. Ossa cinguli membri thoracici (Bones of the pectoral girdle)

The wing bones was composed of scapula, os coracoideum and clavicula.

\section{Scapula (shoulder blade)}

Scapula was found to be curved in the middle and in the form of a sharper sword of the geese. The last vertebra cervicalis specialis (16-17) corresponds to the level of the thickened front end; it was determined that it joins with os coracoideum and furcula to form a joint pit involving the caput humeri.

In measurements taken (Figure 1), there is a significant difference in GL parameter in female and male geese; in male, the scapula length was found to be greater than that of females, while there was no significant difference in Dic parameter $(\mathrm{P}=0.987)$ (Table 1$)$.

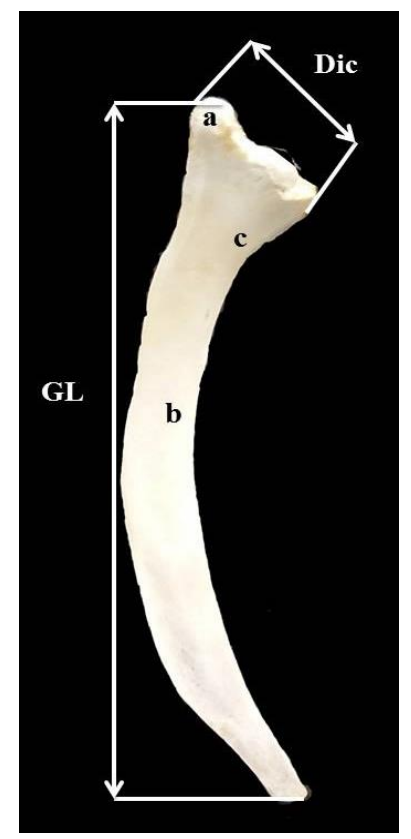

Figure 1. Measurements taken from scapula $(\mathrm{GL}=$ greatest length, Dic= greatest cranial diagonal, $a=$ acromion, facies articularis clavicularis, $b=$ corpus scapulae, facies lateralis, c= collum scapulae). 
Table 1. Comparison of some parameters taken on scapula in male and female geese

\begin{tabular}{cccc}
\hline Parameter & Female $(\mathrm{n}=10)$ & Male $(\mathrm{n}=10)$ & P value \\
\hline GL & $107.31 \pm 1.05$ & $116.63 \pm 0.65$ & $<0.001$ \\
Dic & $22.41 \pm 0.46$ & $22.43 \pm 0.62$ & 0.987 \\
\hline
\end{tabular}

$\mathrm{GL}=$ greatest length, $\mathrm{Dic}=$ greatest cranial diagonal.

\section{Os coracoideum (corvine bone)}

Os coracoideum; clavicle, scapula and humerus that articulates with the narrow end of cranial, and caudal end of which articulates with the sternum was found to be wide (Figure 2). The strongest bone was found between the pectoral girdle bones. Saccus clavicularis was found to pneumatize the os coracoideum.

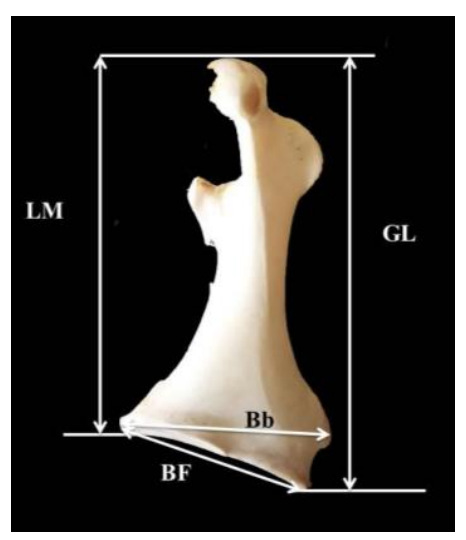

Figure 2. Measurements taken from os coracoideum $(\mathrm{GL}=$ greatest length, $\mathrm{LM}=$ medial length, $\mathrm{Bb}=$ greatest basal breadth, $\mathrm{BF}=$ breadth of the facies articularis basalis).

As shown in Figure 2, GL, Lm, Bb, and BF values were statistically different in male and female geese ( $P$ $<0.001$ ). In male, these parameters were found to be higher than females (Table 2).

Table 2. Comparison of some parameters on os coracoideum in male and female geese

\begin{tabular}{cccc}
\hline Parameter & Female $(\mathrm{n}=10)$ & Male $(\mathrm{n}=10)$ & P value \\
\hline $\mathrm{GL}$ & $78.5 \pm 0.6$ & $87 \pm 0.8$ & $<0.001$ \\
$\mathrm{Lm}$ & $68.4 \pm 0.6$ & $75 \pm 0.6$ & $<0.001$ \\
$\mathrm{Bb}$ & $32.76 \pm 0.6$ & $35.5 \pm 0.4$ & 0.001 \\
$\mathrm{BF}$ & $30.45 \pm 0.4$ & $33.6 \pm 0.4$ & $<0.001$ \\
\hline
\end{tabular}

$\mathrm{GL}=$ greatest length, $\mathrm{Lm}=$ medial length, $\mathrm{Bb}=$ greatest basal breadth, $\mathrm{BF}=$ breadth of the facies articularis basalis.

\section{Clavicula (collar bone)}

In the male and female geese, the clavicula was flat, while the cranial shaped curvature formed the furcula (Figure 3). The upper end of the clavicula was seen to be involved in the formation of the joint cavity of the art. humeri. It was determined that the lower end of the clavicula was formed in the synostosis on the middle plane with the other side and shaped the single bone called furcula. As seen in Table 3, the GL parameter was significantly different between male and female geese, it was longer in males than females. Clavicula was not found to be pneumatized.

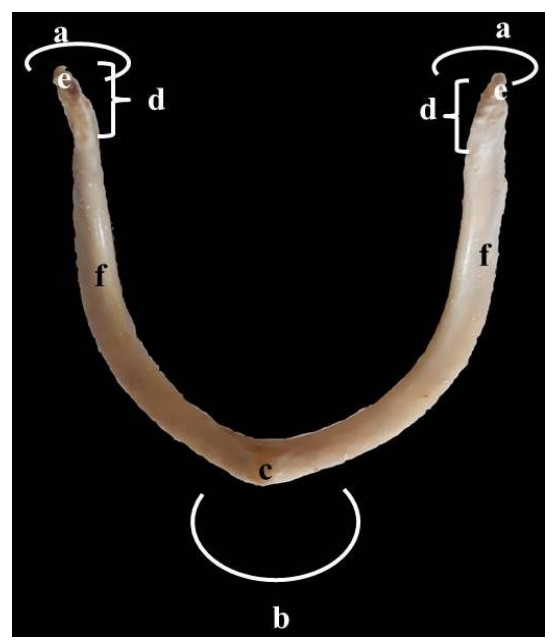

Figure 3. Furcula (Clavicula dexter and Clavicula sinister) $(a=$ extremitas omalis claviculae (Epicleidium, extremitas scapularis), $b=$ extremitas sternalis claviculae, $\mathrm{c}=$ apophysis furculae (Hypocleideum, lamina interclavicularis, proc. interclavicularis), $d=$ facies articularis acrocoracoideae, $\mathrm{e}=$ proc. acromialis, $\mathrm{f}=$ scapus claviculae).

Table 3. Comparison of clavicula lengths in male and female geese

\begin{tabular}{cccc}
\hline Parameter & Female $(\mathrm{n}=10)$ & Male $(\mathrm{n}=10)$ & P value \\
\hline $\mathrm{GL}$ & $66.90 \pm 0.71$ & $73.39 \pm 0.59$ & $<0.001$ \\
\hline
\end{tabular}

$\mathrm{GL}=$ greatest length.

\section{Ossa alae (Bones of the wing)}

Ossa alae was found to be composed of humerus, skeleton antebrachii, carpus, carpometacarpus and digiti (Figure 4).

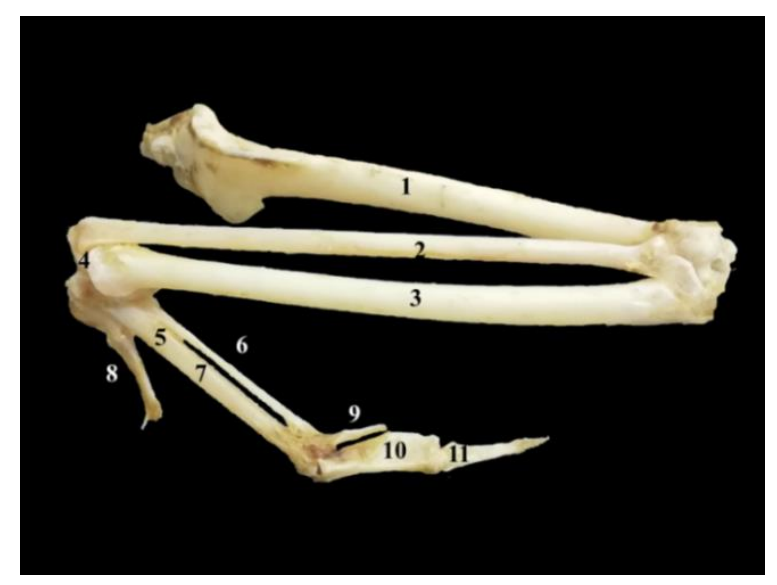

Figure 4. Ossa alae ( $1=$ humerus, $2=$ radius, $3=$ ulna, $4=$ ossa carpi, $5=$ carpometacarpale, $6=$ os metacarpale minus, 7= os metacarpale majus, 8= digiti II, 9= digiti IV, $10=$ phalanx $\mathrm{I}$ in digiti III, 11= phalanx II in digiti III) 


\section{Skeleton brachii (Humerus, arm bone)}

The humerus was the strongest bone in the wing. It was seen that there was an oval structure (caput humeri) on the upper end of the medial. In the dorsolateral of the caput, it was found that the bump was shaped as a tuberculum laterally. In the ventromedial of caput, the tuberculum mediale was found; crista tuberculi medialis was found to extend downwards from the tuberculum mediale. Foramen (for) pneumaticum was seen in the mediodistal of tuberculum mediale. Trochlea humeri was detected at the distal end of the bone. It was found that the larger condylus ulnaris and smaller condylus radialis on trochlea. The trochlea had epicondylus ulnaris and epicondylus radialis (Figure 5). The length of the humerus in the geese was higher than the length of the antebrachium (radius and ulna). Saccus clavicularis was found to pneumatize the humerus.

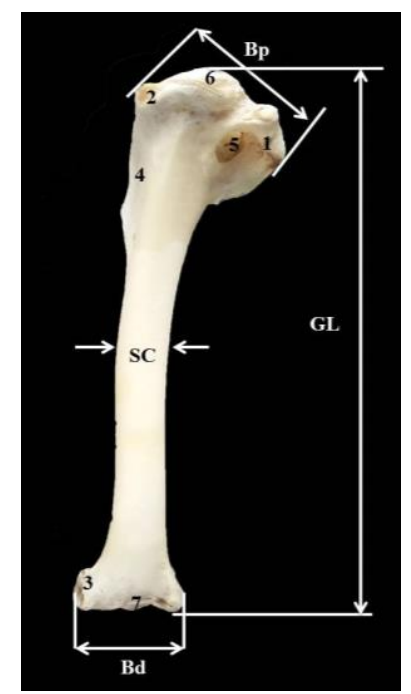

Figure 5. Measurements taken from humerus (1:= tuberculum ventrale, $2=$ tuberculum dorsale, $3=$ condylus dorsalis, $4=$ crista deltopectoralis, $5=$ for. pneumotricipitalis, $6=$ caput humeri, $7=$ fossa olecrani, $\mathrm{GL}=$ greatest length, $\mathrm{Bp}=$ breadth of the proximal end from the tuberculum laterale or dorsale to the tuberculum mediale or ventrale without the crista lateralis, $\mathrm{SC}=$ smallest breadth of the corpus, $\mathrm{Bd}=$ greatest breadth of the distal end).

$\mathrm{GL}, \mathrm{Bd}$, and Bp values were statistically different in male and female geese $(P<0.001)$. In other words, these parameters were higher in males than females. There was no significant difference between the sexes in terms of SC parameter $(\mathrm{P}=0.146)$ (Table 4$)$.

Skeleton antebrachii (Radius-Ulna, Forearm bones) It was determined that the forearm skeleton consisted of thick ulna and thin radius (Figure 6-7). Radius and ulna were not found to be pneumatized.
Table 4. Comparison of some parameters of humerus in male and female geese

\begin{tabular}{cccc}
\hline Parameter & Female $(\mathrm{n}=10)$ & Male $(\mathrm{n}=10)$ & P value \\
\hline GL & $175.02 \pm 1.59$ & $191.28 \pm 1.44$ & $<0.001$ \\
Bp & $37.73 \pm 0.67$ & $42.90 \pm 0.79$ & $<0.001$ \\
SC & $11.84 \pm 0.35$ & $12.50 \pm 0.27$ & 0.148 \\
Bd & $25.56 \pm 0.33$ & $27.91 \pm 0.40$ & $<0.001$ \\
\hline
\end{tabular}

$\mathrm{GL}=$ greatest length, $\mathrm{Bp}=$ breadth of the proximal end from the tuberculum laterale or dorsale to the tuberculum mediale or ventrale without the crista lateralis, $\mathrm{SC}=$ smallest breadth of the corpus, $\mathrm{Bd}=$ greatest breadth of the distal end.

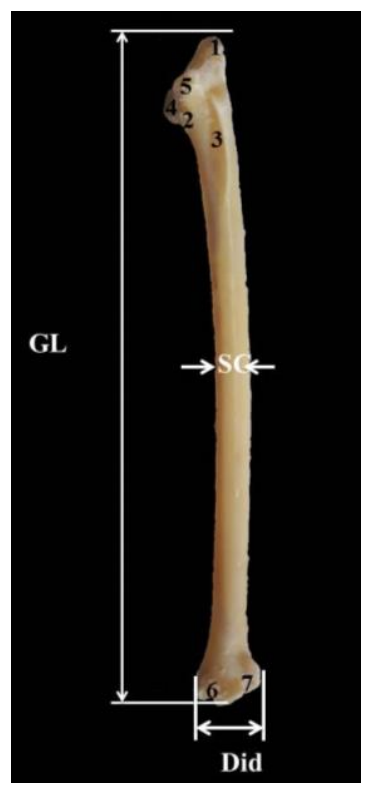

Figure 6. Measurements taken from the ulna (1= olecranon, $2=$ incisura radialis, $3=$ impressio brachialis, $4=$ cotyla dorsalia, $5=$ crista intercotylaris, $6=$ incisura tuberculum carpale, $7=$ sulcus intercondylaris, $\mathrm{GL}=$ greatest length, $\mathrm{SC}=$ smallest breadth of the corpus, $\mathrm{Did}=$ diagonal of the distal end).

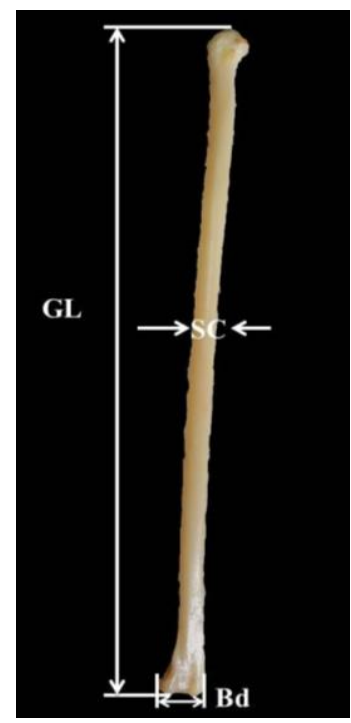

Figure 7. Measurements taken over radius $(\mathrm{GL}=$ greatest length, $\mathrm{SC}=$ smallest breadth of the corpus, $\mathrm{Bd}=$ breadth of the distal end). 


\section{Ulna (Elbow bone)}

Ulna was thicker and longer than the radius. Corpus ulna was almost flat and papilla remigalies were found to be the basis for the adherence of the feather. It was determined that condylus distalis at the bottom was in contact with the radius when performing the art. radioulnaris. It was determined that condylus distalis at the bottom was in contact with os carpi ulnare and os carpi radiale when performing the art. carpoulnaris (Figure 6).

As shown in Fig. 6, GL, Dip, Bp, and Did values were statistically different between male and female geese ( $P$ $<0.001$; $\mathrm{P}=0.001$ ). In other words, these parameters were higher in males than females. There was no significant difference between the sexes in terms of SC value $(\mathrm{P}=0.11)$ (Table 5$)$.

Table 5. Comparison of some parameters taken from ulna in male and female geese

\begin{tabular}{cccc}
\hline Parameter & Female $(\mathrm{n}=10)$ & Male $(\mathrm{n}=10)$ & P value \\
\hline GL & $162,60 \pm 1,26$ & $178,84 \pm 0,83$ & $<0,001$ \\
Dip & $21,40 \pm 0,29$ & $23,45 \pm 0,40$ & 0,001 \\
Bp & $10,53 \pm 0,68$ & $15,69 \pm 0,24$ & $<0,001$ \\
SC & $8,72 \pm 0,32$ & $9,40 \pm 0,24$ & 0,111 \\
Did & $16,57 \pm 0,23$ & $18,81 \pm 0,31$ & $<0,001$
\end{tabular}

GL: Greatest length, Dip: Greatest diagonal of the proximal end from the caudal border of the olecranon to the cranial border of the facies articularis lateralis (dorsalis), Bp: Greatest breadth of the proximal end from the facies articularis medialis (ventralis) to the facies articularis lateralis (dorsalis), SC: Smallest breadth of the corpus, Did: Diagonal of the distal end.

\section{Radius (Rotary bone)}

It was determined that the caput radii at the proximal end of the radius was articulated with the condylus radialis of the humerus.

As a result of the measurements (Figure 7), GL and Bd values were statistically different in male and female geese $(\mathrm{P}<0.001 ; \mathrm{P}=0.001)$. In other words, these parameters were higher in males than females. There was no significant difference between the sexes in terms of SC value ( $\mathrm{P}=0.333$ ) (Table 6).

Table 6. Comparison of some parameters belonging to radius in female and male geese

\begin{tabular}{cccc}
\hline Parameter & Female $(\mathrm{n}=10)$ & Male $(\mathrm{n}=10)$ & P value \\
\hline GL & $154.20 \pm 1.63$ & $169.75 \pm 1.31$ & $<0.001$ \\
SC & $5.94 \pm 0.21$ & $6.28 \pm 0.28$ & 0.335 \\
Bd & $11.53 \pm 0.24$ & $12.69 \pm 0.19$ & 0.001
\end{tabular}

$\mathrm{GL}=$ greatest length, $\mathrm{SC}=$ smallest breadth of the corpus, $\mathrm{Bd}=$ breadth of the distal end.

\section{Skeleton manus (Hand skeleton)}

Ossa carpi (Hand wrist bones)

In the ossa carpi it was seen that only os carpi ulnare and os carpi radiale were on the antebrachial line. Os carpi radiale the two sides appeared to be a blunt edge as sharp as a plump triangle. Os carpi ulnare was found to be in the form of a pipe (Figure 8). The bones in the ossa carpi were not pneumatized.

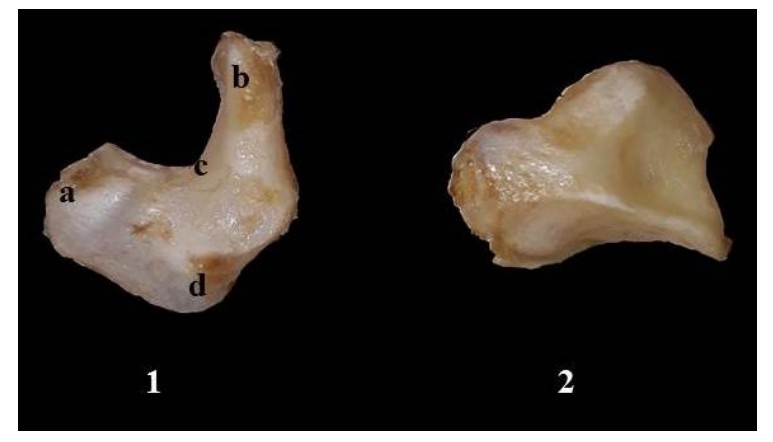

Figure 8. Os carpi ulnare and os carpi radiale $(1=$ os carpi ulnare (Os cuneiform), $a=$ crus breve, $b=$ crus longum, $\mathrm{c}=$ incisura metacarpalis, $\mathrm{d}=$ proc. muscularis, $2=$ os carpi radiale (Os scapholunare)).

\section{Carpometacarpus (Hand wrist-comb bone)}

It was observed that carpometacarpus was composed of a total of 3 bones shaped by the distal order of ossa carpi and metacarpus 2, 3, and 4 . It was determined that os metacarpale majus was longer and stronger and os metacarpale minus was shorter and weaker. Os metacarpale alulare was seen as rudimentary. It has 2 ends as extremitas proximalis carpometacarpi and extremitas distalis carpometacarpi.

In the measurements taken (Figure 9), GL, L, and Did values; male and female geese were found to be statistically different $(\mathrm{P}<0.001 ; \mathrm{P}=0.009)$, while males in females carpometacarpus was determined to be higher than the length of these parameters. In addition, there was no significant difference between the sexes in BP value $(\mathrm{P}=0.23$ ) (Table 7)

Ossa digitorum manus (Hand finger bones)

It was determined that ossa digitorum manus consists of 3 fingers of different size and structure. Of these, 2 were formed from two phalanx. The third finger, the strongest finger, consisted of a total of 3 phalanx. The fourth finger is formed from a single. İt was found that the finger was attached to the proc. alularis located medially at $1.5-2 \mathrm{~cm}$ below the proximal end of the carpometacarpus. 


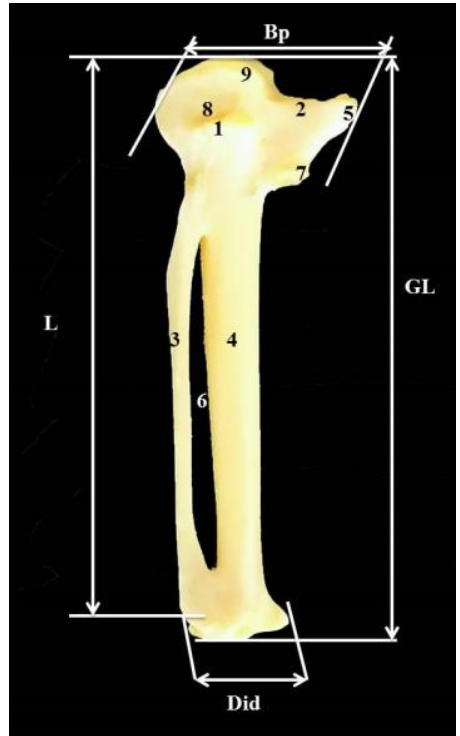

Figure 9. Measurements taken from carpometacarpus (Did= facies articularis digitalis major, $1=$ proc. psiformis, $2=$ trochlea carpalis, $3=$ os metacarpale minus, $4=$ os metacarpale majus, $5=$ proc. extensorius, $6=$ spatium intermetacarpale, $7=$ proc. alularis, $8=$ fossa infratrochlearis, $9=$ trochlea carpalis, $\mathrm{GL}=$ greatest length, $\mathrm{L}=$ length of metacarpus II, $\mathrm{Bp}=$ greatest breadth of the extremitas proximalis, Did= greatest breadth of the extremitas distalis).

Table 7. Comparison of some parameters on carpometacarpus in female and male geese

\begin{tabular}{llll}
\hline Parameter & Female $(\mathrm{n}=10)$ & Male $(\mathrm{n}=10)$ & P value \\
\hline $\mathrm{GL}$ & $94.57 \pm 0.75$ & $100.95 \pm 1.03$ & $<0.001$ \\
$\mathrm{~L}$ & $93.50 \pm 0.83$ & $98.83 \pm 0.82$ & $<0.001$ \\
$\mathrm{Bp}$ & $23.04 \pm 0.25$ & $24.74 \pm 0.64$ & 0.23 \\
Did & $12.98 \pm 0.31$ & $14.20 \pm 0.26$ & 0.009
\end{tabular}

$\overline{\mathrm{GL}}=$ greatest length, $\mathrm{L}=$ length of metacarpus $\mathrm{II}, \mathrm{Bp}=$ greatest breadth of the extremitas proximalis, Did= greatest breadth of the extremitas distalis.

3.1.3. Ossa cinguli membri pelvini (Bones of the pelvic girdle)

Os coxae (Hip bone)

Synsacrum and ossa coxae were combined to form the goose pelvis. It was determined that each of the hip bones consisted of the fusion of three bones, namely os ilium, os pubis, and os ischii. Os ischii and os ilii were determined to shape the acetabulum. Os ilium was the largest bone involved in the formation of coxae. Ala preacetabularis ili, ala postacetabularis ili and corpus ilii were found to consist of three parts. Os ischii was composed of two parts: corpus ischii and ala ischii. İncisura acetabularis, pila ilioischiadica and antitrochanter on corpus ischii were detected. Os pubis consisted of two parts: corpus pubis and scapus pubis. In the measurements taken (Figure 10) GL, LS, LV, CB, SB, and $\mathrm{BE}$ values in male and female geese was statistically different $(\mathrm{P}<0.001, \mathrm{P}=0.006 ; \mathrm{P}=0.002$ ) were seen. In other words, these parameters were higher in males than females. In addition, there was no significant difference between the genders in AA and DIA values $(\mathrm{P}=0,147 ; \mathrm{P}=$ 0,914) (Table 8).

Table 8. Comparison of some parameters on pelvis in male and female geese

\begin{tabular}{lccc}
\hline Parameter & Female $(\mathrm{n}=10)$ & Male $(\mathrm{n}=10)$ & P value \\
\hline GL & $154.27 \pm 1.81$ & $169.91 \pm 1.68$ & $<0.001$ \\
LS & $151.44 \pm 1.44$ & $165.61 \pm 1.76$ & $<0.001$ \\
LV & $137.24 \pm 1.78$ & $150.18 \pm 2.47$ & $<0.001$ \\
CB & $35.31 \pm 0.56$ & $39.63 \pm 0.52$ & $<0.001$ \\
SB & $26.92 \pm 0.40$ & $29.01 \pm 0.53$ & 0.006 \\
AA & $45.73 \pm 1.74$ & $48.62 \pm 0.77$ & 0.147 \\
DİA & $12.81 \pm 0.32$ & $12.87 \pm 0.41$ & 0.914 \\
BA & $50.85 \pm 0.93$ & $56.30 \pm 1.20$ & 0.002 \\
\hline
\end{tabular}

$\mathrm{GL}=$ greatest length (without pubis), $\mathrm{LS}=$ length from the cranial border of the ilia to the spinaeilio-caudales, $\mathrm{LV}=$ length along the vertebrae, centrally, $\mathrm{CB}=$ cranial breadth, $\mathrm{SB}=$ smallest breadth of the partes glutaea, $\mathrm{AA}=$ breadth between the borders of the acetabulum, measured at the narrowest part, DİA= diameter of one acetabulum: greatest distance including the labium acetabuli, $\mathrm{BA}=$ breadth in the middle: breadth cross the two antitrochanter.

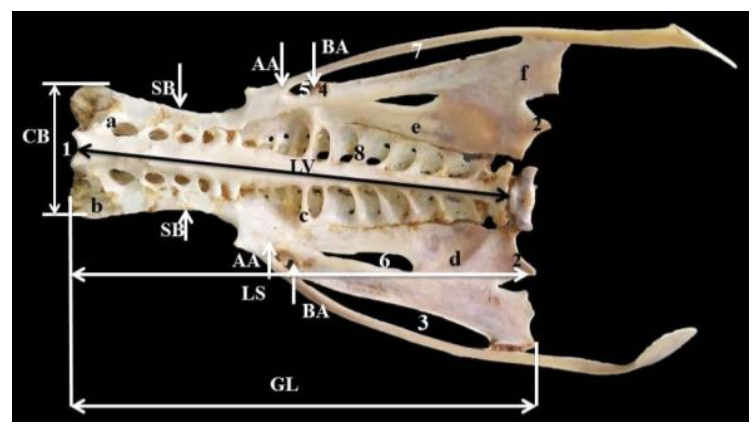

Figure 10. Ventral view of the pelvis $(\mathrm{LV}=$ sulcus ventralis synsacri, $\mathrm{CB}=$ extremitas cranialis synsacri, $1=$ margo iliocranialis, $2=$ spina iliocaudalis, Proc. marginis caudalis, $3=$ fenestra ischiopubica, $4=$ antitrochanter, $5=$ for. obturatum, $6=$ for. ilioischiadicum, $7=$ scapus pubis, $8=$ forr. intertransversariae, $a=$ crista iliaca lateralis, $b=$ ala preacetabularis ilii, $c=$ proc. costalis, $d=$ fossa renalis, $\mathrm{e}=$ ala postacetabularis $\mathrm{ilii}, \mathrm{f}=$ ala ischii, $\mathrm{GL}=$ greatest length (without pubis), LS= length from the cranial border of the ilia to the spinaeilio-caudales, $\mathrm{LV}=$ length along the vertebrae, centrally, $\mathrm{CB}=$ cranial breadth, $\mathrm{SB}=$ smallest breadth of the partes glutae, $\mathrm{AA}=$ breadth between the borders of the acetabulum, measured at the narrowest part, BA= breadth in the middle: breadth cross the two antitrochanter).

\subsubsection{Ossa membri pelvini (Bones of the pelvic limb) Femur (thigh bone)}

Caput femoris and trochanter major (femoris) were found to be almost the same level. Trochanter minor was 
found in the distomedial of collum femoris (Figure 11). Trochlea femoris was seen on the anterior aspect of the distal end of the femur. Behind the distal end of the femur was found 2 condylus. Condylus medialis with the tibia and the larger condylus lateralis tibia and caput fibulae rudimentary with the joint was determined. Femur was not pneumatized.

As a result of the measurements (Figure 11), GL, Lm, Bp, $\mathrm{Bd}$, and Dd values were statistically different in male and female geese $(\mathrm{P}<0.001 ; \mathrm{P}=0.01)$. In other words, these parameters were higher in males than females. In addition, there was no significant difference between Dp and $\mathrm{SC}$ values $(\mathrm{P}=0.11 ; \mathrm{P}=0.07$ ) (Table 9).

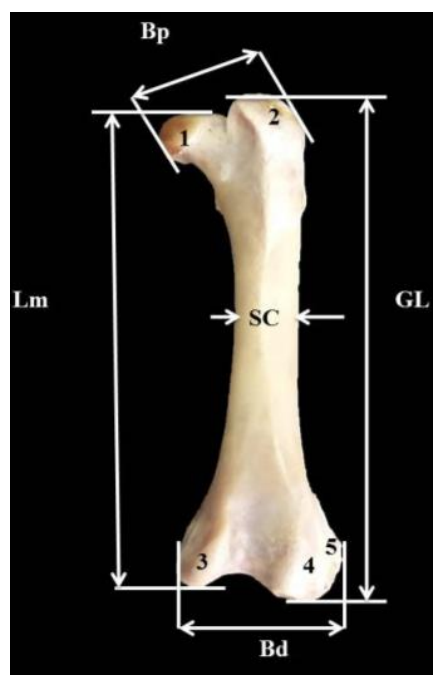

Figure 11. Measurements taken from the femur (1= caput femoris, 2= trochanter major (femoris), $3=$ condylus medialis, $4=$ condylus lateralis, $5=$ condylus fibularis, $\mathrm{GL}=$ greatest length, $\mathrm{Lm}=$ medial length, $\mathrm{Bp}=$ greatest breadth of the proximal end, $\mathrm{SC}=$ smallest breadth of the corpus, $\mathrm{Bd}=$ greatest breadth of the distal end).

Table 9. Comparison of some parameters taken on femur in male and female geese

\begin{tabular}{cccc}
\hline Parameter & Female $(\mathrm{n}=10)$ & Male $(\mathrm{n}=10)$ & P value \\
\hline GL & $86.85 \pm 0.98$ & $93.87 \pm 1.12$ & $<0.001$ \\
Lm & $82.26 \pm 0.87$ & $88.36 \pm 1.01$ & $<0.001$ \\
Bp & $22.43 \pm 0.26$ & $24.66 \pm 0.32$ & $<0.001$ \\
Dp & $17.00 \pm 0.43$ & $18.54 \pm 0.33$ & 0.11 \\
SC & $9.44 \pm 0.13$ & $10.09 \pm 0.17$ & 0.07 \\
Bd & $22.99 \pm 0.35$ & $24.94 \pm 0.37$ & 0.01 \\
Dd & $18.22 \pm 0.32$ & $20.05 \pm 0.32$ & 0.01 \\
\hline
\end{tabular}

$\mathrm{GL}=$ greatest length, $\mathrm{Lm}=$ medial length, $\mathrm{Bp}=$ greatest breadth of the proximal end, $\mathrm{Dp}=$ greatest depth of the proximal end, $\mathrm{SC}=$ smallest breadth of the corpus, $\mathrm{Bd}=$ greatest breadth of the distal end, $\mathrm{Dd}=$ greatest depth of the distal end.

\section{Patella (Knee cap bone)}

The patella; mm. femorotibialis and $\mathrm{m}$. iliotibialis were found to be a small sesamoid bone within the common tendon and at the level of the trochlea femoris. The male and female geese were triangular.

Tibiotarsus (Foot-leg wrist bone)

It was determined that the goose skeleton consisted of the strong tibiotarsus and weak fibula, and tibiotarsus was not pneumatized. It was found that tibiotarsus was approximately 2 times longer than femur.

As a result of the measurements (Figure 12), GL, La, Dip, $\mathrm{Bd}$, and Dd values were statistically different in male and female geese $(\mathrm{P}<0.001 ; \mathrm{P}=0.010 ; \mathrm{P}=0.001)$. In other words, these parameters were higher in males than females. In addition, there was no significant difference between the sexes in terms of SC $(P=0.270)$ (Table 10).

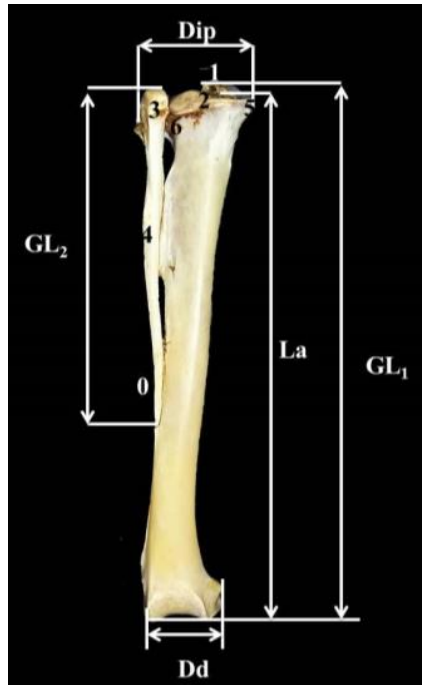

Figure 12. Measurements taken from tibiotarsus and fibula $(0=$ spina fibulae, $1=$ proc. cnemialis, $2=$ tuberculum centrale, $3=$ caput fibulae, $4=$ corpus fibulae, Crista fibularis, $5=$ condylus medialis femoralis, $6=$ condylus lateralis femoralis, GL1= greatest length of tibiotarsus, GL2= greatest length of the fibula, $\mathrm{La}=$ axial length, Dip= greatest diagonal of the proximal end, $\mathrm{Dd}=$ depth of the distal end).

Table 10. Comparison of some parameters of tibiotarsus in male and female geese

\begin{tabular}{cccc}
\hline Parameter & Female $(\mathrm{n}=10)$ & Male $(\mathrm{n}=10)$ & P value \\
\hline GL & $160.94 \pm 1.88$ & $174.20 \pm 1.28$ & $<0.001$ \\
La & $151.89 \pm 1.87$ & $167.64 \pm 1.32$ & $<0.001$ \\
Dip & $28.36 \pm 0.65$ & $30.65 \pm 0.45$ & 0.010 \\
SC & $8.48 \pm 1.64$ & $8.20 \pm 0.18$ & 0.270 \\
Bd & $18.55 \pm 0.25$ & $20.02 \pm 0.14$ & $<0.001$ \\
Dd & $17.47 \pm 0.75$ & $20.63 \pm 0.32$ & 0.001 \\
\hline
\end{tabular}

$\mathrm{GL}=$ greatest length of tibiotarsus, $\mathrm{La}=$ axial length, $\mathrm{Dip}=$ greatest diagonal of the proximal end, $\mathrm{SC}=$ smallest breadth of the corpus, $\mathrm{Bd}=$ greatest breadth of the distal end, $\mathrm{Dd}=$ depth of the distal end.

\section{Fibula (Calf bone)}

It was observed that the fibula was proximal to the distal to a flat rod. It was determined that the tapered corpus of 
the fibula was progressively tapering to the distal length of the tibia. It was observed that the fibula was bounded by two spatium interosseum, proximal and distal along its length. In the measurements taken as shown in Figure 12 , it was determined that there was no significant difference between females and males in fibula length $(\mathrm{P}$ $=0.189$ ).

\section{Ossa pedis (Foot bones)}

Ossa tarsi (Ankle bones)

Tarsal bones were not found independently. The proximal row of ossa tarsi was found to be fused with the distal part of tibiotarsus and the distal row of ossa tarsi with the proximal metatarsus.

Tarsometatarsus (Foot wrist-comb)

Tarsometatarsus was a composite bone composed of os metatarsale II, os metatarsale III, os metatarsale IV and ossa tarsi. Os metatarsale I and V were absent. The first finger in the distal part of the os metatarsal I was smaller and did not fuse with them. Hypotarsus was found to constitute the proximal boundary of os metatarsale III. It was determined that there were 3 crista hypotharsis in the hypotarsus of geese and the longest of crista medialis hypotarsi. The distal end of the one-piece metatarsus was divided into 3 trochlea with a very distinctive 2 notches. It was determined that there was a bone spur on the facies medialis aspect of extremitas distalis tarsometatarsi in male and female geese. This formation was better developed in males.

The statistical data generated as a result of the measurements taken in Figure 13; GL, Bp, SC, and Bd showed significant differences between male and female geese $(\mathrm{P}<0.001 ; \mathrm{P}=0.001)$. In other words, all of these parameters were found to be significantly longer in males (Table 11).

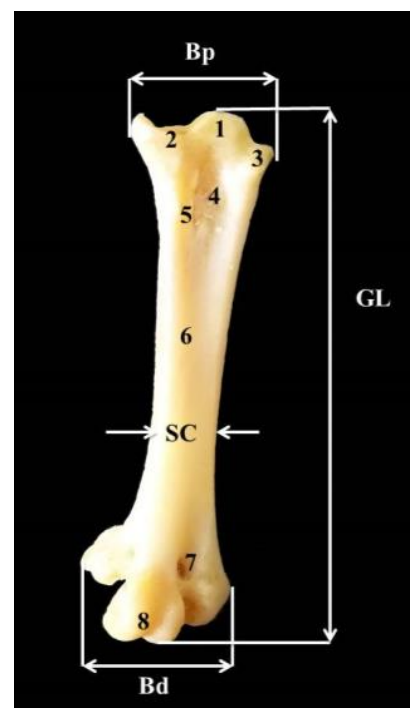

Figure 13. Measurements taken by tarsometatarsus (1= eminentia intercotylaris, $2=$ cotyla medialis, $3=$ cotyla lateralis, $4=$ sulcus extensorius, $5=$ tuberositas $\mathrm{m}$. tibialis cranialis, $6=$ facies dorsalis, $7=$ for. vasculare distale, $8=$ trochlea metatarsi III, GL= greatest length, $\mathrm{Bp}=$ greatest breadth of the proximal end, $\mathrm{SC}=$ smallest breadth of the corpus, $\mathrm{Bd}=$ greatest breadth of the distal end).
Table 11. Comparison of some parameters of tarsometatarsus in male and female geese

\begin{tabular}{cccc}
\hline Parameter & Female $(\mathrm{n}=10)$ & Male $(\mathrm{n}=10)$ & P value \\
\hline GL & $93.15 \pm 1.19$ & $101.64 \pm 0.88$ & $<0.001$ \\
Bp & $19.05 \pm 0.35$ & $20.93 \pm 0.30$ & 0.001 \\
SC & $8.77 \pm 0.11$ & $9.41 \pm 0.11$ & 0.001 \\
Bd & $21.48 \pm 0.39$ & $24.03 \pm 0.32$ & $<0.001$
\end{tabular}

$\mathrm{GL}=$ greatest length, $\mathrm{Bp}=$ greatest breadth of the proximal end, $\mathrm{SC}=$ smallest breadth of the corpus, $\mathrm{Bd}=$ greatest breadth of the distal end.

Ossa digitorum pedis (The foot toe bones)

There were four fingers on the goose leg. The first finger in the medial was caudal, while the $2 \mathrm{nd}$, 3rd, and 4 th fingers were directed towards the cranial.

Phalanges (Finger bones)

Two phalanxs were found on the first finger, three on the second finger, four on the third, and five on the fourth finger.

\section{Discussion}

While the length of the scapula was $61.8 \mathrm{~mm}$ (Özgel et al., 2002), it was measured as $116.63 \pm 0.65 \mathrm{~mm}$ in male geese and $107.31 \pm 1.05 \mathrm{~mm}$ in female geese. The diverticulum subscapulare of the saccus clavicularis in geese has been reported to pneumatize the scapula (Onuk, 2008). In this study, it was determined that saccus clavicularis had pneumatized scapula. It has been reported that the length of the bald ibis os coracoideum is 46-51 mm (Özgel et al., 2002). The length of the bone was $78.5 \pm 0.6 \mathrm{~mm}$ in female geese and $87 \pm 0.8 \mathrm{~mm}$ in male geese. It is reported that there is no pneumatization in the os coracoideum (Hogg, 1984a) in chicken, duck (Çevik Demirkan, 2002) and geese (Onuk, 2008) have been reported to be pneumatized. In the present study, it was determined that os coracoideum was pneumatized.

The forward curvature of the clavicula was less pronounced and stronger in the hen and rooster, and almost flat in the turkey (Gültekin, 1957). In male and female geese, the clavicula was found to be flat but with a distinct curvature, it was seen that two clavicles were joined together in synostosis. While clavicula was reported as a pneumatized bone in the duck (Çevik Demirkan, 2002), clavicle was not pneumatized in geese. It has been reported that humerus is longer than antebrachium in chicken, domestic duck and quail (Çevik Demirkan, 2002). In pigeons, antebrachium was reported to be longer than humerus (Ylddı et al., 1998). In the study, it was found that humerus was longer than antebrachium in female and male geese. The length of the humerus is $51.80 \pm 0.49 \mathrm{~mm}$ in partridge, $67.77 \pm 0.55$ $\mathrm{mm}$ in pheasant (Lök and Yalçın, 2007), in the longlegged buzzard 100-110 mm (Atalar et al., 2007), in goose $172.5 \mathrm{~mm}$ (Allison et al., 2006), $72.5 \mathrm{~mm}$ in the chicken, $87.4 \mathrm{~mm}$ in the domestic duck, $46.1 \mathrm{~mm}$ in the pigeon (Ylldı et al., 1998), $95.84 \pm 1.63 \mathrm{~mm}$ in the female ducks, 106 in the male ducks. (Çevik Demirkan, 2002). In 
this study, humerus length was $175.02 \pm 1.59 \mathrm{~mm}$ in female geese and $191.28 \pm 1.44 \mathrm{~mm}$ in male. The humerus length values we found were higher than those of the other birds, but similar to the Canadian geese. The humerus in the blue-headed parrot is reported to be pneumatized (McKibben and Harrison, 1986). It was reported that diverticulum humerale of saccus clavicularis in the geese had pneumatized humerus (Onuk, 2008). In our study, saccus clavicularis was found to pneumatize the humerus.

The average length of ulna is $29.7 \mathrm{~mm}$ in domestic quail, $29.4 \mathrm{~mm}$ in wild quail (Yaman, 1997), $49.74 \pm 0.46 \mathrm{~mm}$ in partridge, $61.53 \pm 0.50 \mathrm{~mm}$ in pheasants (Lök and Yalçın, 2007), 110-130 mm (Atalar et al., 2007) was reported as $100.1 \pm 3.0 \mathrm{~mm}$ (Charuta et al., 2005) in males of the domestic duck. In our study, the length of ulna was $162.60 \pm 1.26 \mathrm{~mm}$ in female geese and $178.84 \pm 0.83 \mathrm{~mm}$ in male geese. Papillae remigalis, which were the basis for the attachment of feathers to ulna, were clearly seen. While the curvature of corpus ulnae is less pronounced in chickens and ducks, it is stated that it is more prominent in goose and duck (Nickel et al., 1977). There was a slight curvature in the corpus ulnae. Mean radius length was $44.54 \pm 0.44 \mathrm{~mm}$ in partridge, $56.09 \pm 0.47 \mathrm{~mm}$ in pheasants (Lök and Yalçın, 2007), female Pekin duck 94.9 $\pm 2.1 \mathrm{~mm}$, male Pekin duck $91.0 \pm 13.59 \mathrm{~mm}$ (Charuta et al., 2005). In this study, the mean radius length was $154.20 \pm 1.63 \mathrm{~mm}$ in female geese and $169.75 \pm 1.31 \mathrm{~mm}$ in male geese. It was observed that the poultry species compared with them were extremely large. It was determined that the radius and ulna were equal in length (Rezk, 2015) in the cattle egret and that the ulna was long in radius. The largest width at the distal end was $11.53 \pm 0.24 \mathrm{~mm}$ in male geese and $12.69 \pm 0.19 \mathrm{~mm}$ in female geese, whereas Charuta et al., (2005) in the study of Pekin duck in males $9.4 \pm 0.6 \mathrm{~mm}$ female $9.0 \pm 0.3 \mathrm{~mm}$. It was reported that radius and ulna has not been pneumatized in the partridge, pheasant and long-legged buzzard from birds (King, 1957; Lök and Yalçın, 2007). Antebrachium was not pneumatized in geese.

It was reported that os carpi radiale is short and quadrangular in duck (Çevik Demirkan, 2002), it is almost rectangular in partridge and rectangular and bow tied with pheasants (Lök and Yalçın, 2007). In the study, it was observed that the two sides were shaped two blunt edge one sharp edge, pointed, triangular shaped. Os carpi radiale is generally similar to geometric shapes, but the reported figures and findings are not similar. Os carpi ulnare in duck (Çevik Demirkan, 2002), pheasant and partridge (Lök and Yalçın, 2007) V shaped, cattle egret (Rezk, 2015) U-shaped was stated. In this study, os carpi ulnare was seen as a pipe shaped. Os carpi ulnare's shape did not match the findings of other reported studies Mean carpometacarpus length was $29.94 \pm 0.31 \mathrm{~mm}$ in partridge, $34.82 \pm 0.26 \mathrm{~mm}$ in pheasant (Lök and Yalçın, 2007), 59-71.2 mm long-legged buzzard (Atalar et al., 2007), male and female Pekin duck in $75.0 \pm 1.7-73.3 \pm$ $2.0 \mathrm{~mm}$ (Charuta et al., 2005). In the study, the length of carpometacarpus was determined as $94.57 \pm 0.75 \mathrm{~mm}$ in female geese and $100.95 \pm 1.03 \mathrm{~mm}$ in male geese. Carpometacarpus length was higher in geese compared to other studies.

It was observed that the apex pubis of the os pubis ended in bent to the ventromedian. It was reported that os pubis did not participate in the formation of acetabulum in chicken and duck (Dursun, 2007; Çevik Demirkan, 2002). It was observed that os pubis did not participate in acetabulum formation in geese. It have been reported that ilium, ischium and pubis to be pneumatized in the blue-headed parrot (McKibben and Harrison, 1986). Saccus abdominalis has been reported to pneumatize coxa (King and McLelland, 1975). There was no indication of pneumatization of coxa in chickens (Hogg, 1984b). In the wild duck (Çevik Demirkan et al., 2006) and the goose (Onuk, 2008), it was stated that saccus abdominalis pneumatized to the synsacrum. In this study, it was found that synsacrum was pneumatized by saccus abdominalis.

The average length of the femur was reported as 81.5 $\mathrm{mm}$ (Allison et al., 2006) in Canadian geese, $60.14 \pm 0.49$ $\mathrm{mm}$ in female ducks and $60.92 \pm 0.93 \mathrm{~mm}$ in male ducks (Çevik Demirkan, 2002). In this study, femur length was $86.85 \pm 0.98 \mathrm{~mm}$ in female geese and $93.87 \pm 1.12 \mathrm{~mm}$ in male geese. The length of the femur was similar to that of the Canada goose while it was higher than the other poultry. It was reported that there was no pneumatization in the femur in the hens (Hogg, 1984a). Diverticula femoralia of saccus abdominalis was reported to pneumatize the femur in geese (Onuk, 2008). In the study, it was seen that the femur was pneumatized by saccus abdominalis.

It is reported that the patella has a triangular appearance in the partridges, and in pheasants it resembles the talus of mammals (Başoğul and Beşoluk, 2016), rectangular female ducks and square in shape male ducks (Çevik Demirkan, 2002). In our study, it was observed that patella was triangular in male and female geese.

The average length of tibiotarsus was measured as 150.5 mm (Allison et al., 2006) in Canadian geese, $94.9 \pm 1.2$ in female ducks and $102.5 \pm 0.94 \mathrm{~mm}$ in male ducks (Çevik Demirkan, 2002). This study measured $160.94 \pm 1.88$ $\mathrm{mm}$ in female geese and $174.20 \pm 1.28 \mathrm{~mm}$ in male. It has been reported that tibiotarsus in pigeons and chickens is longer than $1 / 3$ of femur from femur (Dursun, 2007). As reported in the literature (Nickel et al., 1977; Çevik Demirkan, 2002) tibiotarsus was found to be $50 \%$ longer than the femur. As in the duck (Çevik Demirkan, 2002), it was observed that the fibula was extended to the distal part of the tibia length and to limit the two spatium interosseum, proximal and distal along its length.

In the study, it was determined that tarsometatarsus, which is the only one in the geese, was formed by the fusion of os metatarsale II, os metatarsale III (principal) and os metatarsale IV. In hypotarsus, it is reported that in some birds there is only one crista and sulcus, most birds have more than one crista and sulcus (N.A.A., 1993). In 
the geese 3 cristae hypotharsia (crista lateralis hypotarsi, crista intermedia hypotarsi and crista medialis hypotharsia) was found and crista medianoplantaris (crista medialis hypotarsia) to be the longest. In extremitas distalis tarsometatarsia, trochleas (trochlea metatarsi II, troclea metatarsi III, trochlea metatarsi IV) belonging to each tarsometatarsus were seen. It was reported in some birds (N.A.A., 1993) that adjoint trochlea accessoria wasn't detected. Among the trochlea's were the incisura intertrochlearis lateralis and the incisura intertrochlearis medialis. The plantar of the trochlea's had a deep pit fossa supratrochlearis plantaris. Canalis interosseus distalis was not apparent, but for. vasculare distale was a big hole. The tallest bone of the tarsometatarsus was chicken and the shortest bone was reported as goose (Gültekin, 1966; N.A.A., 1993). However, in our study, we found that the tarsometatarsus length of larger other poultry tarsometatarsus (Zeffer and Lindhe Norberg, 2003) because of this information is contrary. In most birds, tarsometatarsus is shorter than tibiotarsus; two bones were reported to have approximately equal length in the rain bird (King and McLelland, 1984). It was determined that tibiotarsus length was greater than tarsometatarsus in geese. Tarsometatarsus length; $38.5 \mathrm{~mm}$ in common buzzard, $45.6 \mathrm{~mm}$ in mallard duck, $18.9 \mathrm{~mm}$ in sparrow, $17.9 \mathrm{~mm}$ in finch, $104.8 \mathrm{~mm}$ in gold eagle, $78.3 \mathrm{~mm}$ in diver bird (Zeffer and Lindhe Norberg, 2003). This length was $93.15 \pm 1.19 \mathrm{~mm}$ in female geese and it was $101.64 \pm$ $0.88 \mathrm{~mm}$ in male geese.

\section{Conclusion}

Goose (Anser anser domesticus) is one of the poultry animals shown as most examples in veterinary anatomy teaching. It is also the geographical sign of Kars region. Therefore, the bones of adult geese were examined in our study. As a result, in this study, morphometric and morphologic values of examined bones of adult geese were determined and contributed to the elimination of the information in this area. It is thought that obtained findings will contribute in scientific research, evaluations of sexual dimorphism, zooarchaeological studies and operations on poultry animals.

\section{Author Contributions}

All authors' contributions were equal.

\section{Conflict of Interest}

The authors declare that there is no conflict of interest.

\section{Acknowledgements}

The current study was supported by Scientific Research Projects Coordination of Kafkas University (2018-TS-09). The present study was summarized from a $\mathrm{PhD}$ thesis. This study was presented in oral International Congress on Domestic Animal Breeding Genetics and Husbandry. August 12-14, 2020, İzmir, Turkey.

\section{References}

Allison R, Tumarkin-Deratzian, David RV, Peter D. 2006. Bone surface texture as an ontogenetic indicator in long bones of the Canada goose Branta canadensis (Anseriformes: Anatidae). Zool J Linnean Soc, 148: 133-168. DOI: 10.1111/j.1096-3642.2006.00232.x.

Aslan C. 2013. Kaz besleme ve yetiștiriciliği, Genişletilmiş 2. baskı, Medipres Matbaacılık Yayıncılık Lt. Şti, Malatya, Turkey.

Atalar Ö, Kürtül İ, Özdemir D. 2007. Morphological and morphometric approach to the bones of the wings in the Long-Legged Buzzard (Buteo Rufinus). FÜ Sağ Bil Derg, 21: 163-166

Başoğul M, Beşoluk K. 2016. Kaya kekliği (Alectoris graeca) ve sülünlerde (Phasianus colchicus) bacak kemikleri (Ossa membri pelvini) üzerinde karşılaştırmalı makro anatomik araştırmalar. Turk J Vet Anim Sci, 1: 13-22.

Charuta A, Bartyzel BJ, Karbowicz M, Kobryń H. 2005. Morphology and morphometry of the antebrachial skeleton and bones of hand of the domestic Pekin duck. Vet Med Zoot 51: 26-30.

Çevik Demirkan A, Kürtül İ, Hazıroğlu RM. 2006. Gross morphological features of the lung and air sac in the Japanese quail. J Vet Med Sci, 68: 909-913.

Çevik Demirkan A. 2002. Ördekte iskelet sistemi. AÜ Sağlık Bilimleri Enstitüsü, PhD. Thesis, Ankara.

Demirsoy A. 1995. Yaşamın temel kuralları. omurgalılar/amniyota (sürüngenler, kuşlar ve memeliler). Vol. 3, Bölüm 2, Meteksan Yayınevi, Ankara, Turkey.

Dursun N. 2007. Evcil kuşların anatomisi. Medisan yayınevi, 11. Baskl, Ankara, Turkey.

Dyce KM, Sack WO, Wensing CJG. 1987. Textbook of veterinary anatomy. Philadelphia, USA.

Gültekin M.1966. Evcil memeli ve kanatlıların karşılaştırmalı osteologia'sı. Ankara Üniversitesi Basımevi, Ankara, Turkey.

Gültekin M.1957. Yerli tavuk ve horoz iskeleti ile yerli hindi iskeleti arasındaki sabit makro-anatomik ayrımlar üzerinde incelemeler. Ankara Üniv Vet Fak Derg, 4: 6-14.

Hogg DA. 1984a. The development of pneumatisation in the postcranial skeleton of the domestic fowl. J Anat, 139: 105 113.

Hogg DA. 1984b. The distribution of pneumatisation in the skeleton of the adult domestic fowl. J Anat, 138: 617-629.

Kılıç E, Yayla S, Ermutlu CŞ, Aydın U. 2018. Köpek yavrularında diafizer femur kırığının sağaltımı için kaz radius'u kullanımı. V. International Multidisciplinary Congress of Eurasia, Barcelona-Spain, 24-26 July.

King AS, McLelland J. 1984. Birds their structure and function. Bailliere Tindal, London, UK.

King AS, McLelland J. 1975. Outlines of avian anatomy. Bailliere Tindal, London, UK.

King AS. 1957. The aerated bones of gallus domesticus. Acta Anat, 31: 220-230.

König HE, Korbel R, Liebich HG. 2016. Avian anatomy textbook and colour atlas. $5 \mathrm{~m}$ publishing, 2. Edition, Sheffield, UK.

Kuru, M. 1987. Omurgalı hayvanlar. Atatürk Üniversitesi Yayınları, Erzurum, Turkey.

Lök S, Yalçın H. 2007. Kaya kekliği (A. Graeca) ve sülünlerde (P. Colchicus) kanat kemikleri (ossea alae) üzerinde karşılaştırmalı makroanatomik araştırmalar. Vet Bil Derg, 21: 85-94.

McKibben JS, Harrison GJ. 1986. Clinical anatomy with emphasis on the amazon parrot. clinical avian medicine and surgery, WB Saunders, Philadelphia, USA.

McLelland J. 1990. A Colour atlas of avian anatomy. Wolfe 
Publishing Ltd, Aylesbury, UK.

Mussa MT, Kamal MM, Mahmud MAA, Sarker BK, Jalil MA, Das SK. 2015. Evaluation of a rapid and efficient method for preparation of skeletons of rabbit and goose. Bangladesh J Vet Med, 13: 27-31. DOI: 10.3329/bjvm.v13i2.26617.

Nomina Anatomica Avium (N.A.A.) 1993. International committe on avian anatomical nomenclature: Nomina anatomica avium , 2nd ed., World Association of Veterinary Anatomist, Cambridge, Massachusetts, USA.

Nickel R, Schummer A, Seiferle E. 1977. Anatomy of the domestic birds. Verlag Paul Parey, Berlin, Germany.

Onuk B. 2008. Kazda (Anser anser domesticus) solunum sisteminin anatomisi. OMÜ, Sağlık Bilimleri Enstitüsü, $\mathrm{PhD}$. Thesis, Samsun, Turkey.

Özgel Ö, Düzler A, Ümran Bozkurt E. 2002. Macroanatomical investigations on ossa cinguli membri thoracici in bald ibis. Indian Vet J, 79: 700-707.

Rezk HM. 2015. Anatomical investigation on the appendicular skeleton of the cattle egret (Bubulcus ibis). J Exp Clin Anat, 14:5-12. DOI: 10.4103/1596-2393.158919.
Taşbaş M, Tecirlioğlu S. 1965. Maserasyon tekniği üzerinde araştırmalar. Ankara Üniv Vet Fak Derg, 12: 324-330.

Tilki M, Saatçi M. 2013. Her yönüyle kaz yetiștiriciliği. 1. Baskı, Salmat Basım Yayıncılık, Ankara, Turkey.

Von Den Driesch A. 1976. A Guide to the measurement of animal bones from archaeological sites. Peabody Museum Bulletin I. Cambridge M.A. Harvard University, USA.

Yaman M. 1997. Bildırcınların, Coturnix coturnix Linnaeus, 1758 (Aves: Gall.) Evcil ve yabani alt türlerinde kanat iskeletini olușturan humerus, radius, ulna ve manus kemiklerinin biyometrik ölçümlerinin karşılaştırılması. SÜ Fen Bilimleri Enstitüsü, Master Thesis, Konya, Turkeu

Yıldız H, Yıldız B, Eren G. 1998. Tavuk, yerli ördek, güvercin ve bıldırcınlarda humerus ile antebrachium kemikleri üzerine morfometrik araştırma. UÜ Vet Fak Derg, 17: 87-91.

Zeffer A, Lindhe Norberg UM. 2003. Leg morphology and locomotion in birds: Requirements for force and speed during ankle flexion. J Exp Biol, 206: 1085-1097. DOI: 10.1242/jeb.00208. 